\title{
SOME NeW DATA ON THE MORPHOLOGY OF SPINITECTUS INERMIS (Nematoda: Cystidicolidae), a Rare parasite Of eEls, AS REVEALED BY SEM
}

\author{
MORAVEC F**
}

\section{Summary :}

Scanning electron microscopy studies of two males of Spinitectus inermis (Zeder, 1800), a stomach parasite of eels, Anguilla anguilla (L.), in Europe made it possible to describe in detail the apical structure of this rare nematode as well as the morphology of the male caudal end. The structure of the mouth of $S$. inermis is intermediate between those of freshwater and marine species as regards the configuration of the pseudolabia and the presence of sublabia. This is probably associated with the host which occurs in both habitats. The presence of a median, unpaired preanal papilla is reported in the male of $S$. inermis for the first time.

KEY WORDS : Spinitectus, nematode, parasite, Anguilla, morphology

MOTS CLÉS: Spinitectus, nématode, parasite, Anguilla, morphologie.
Résumé : DONNÉES NOUVELLES SUR LA MORPHOLOGIE EN MICROSCOPIE Électronique à balayage de SPINITECTUS INERMis (Nematoda: CYSTIDICOLIDAE), PARASITE PEU FRÉQUENT DE L'ANGUILLE

L'étude en microscopie électronique à balayage de deux mâles de Spinitectus inermis (Zeder, 1800), parasite digestif de l'anguille, Anguilla anguilla (L.) en Europe, a permis de détailler la structure apicale de ce nématode rare, ainsi que la morphologie de l'extrémité caudale du mâle. La structure de la partie buccale de S. inermis se situe entre celles des espèces de mer et d'eau douce, pour ce qui concerne la configuration des pseudolabia et la présence de sublabia. Ceci est probablement lié à la présence de l'hôte dans les deux habitats. Pour la première fois, l'existence d'une papille médiane préanale est signalée chez le mâle de S. inermis.

\section{INTRODUCTION}

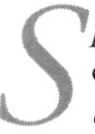
pinitectus inermis (Zeder, 1800) is a rare, specific nematode of the stomach of eels, Anguilla anguilla (L.) in Europe, where it is widespread in the North, Baltic and Mediterranean Seas basins (Moravec, 1994). Although this species was known to helminthologists as early as at the beginning of the last century, the knowledge of its morphology remained poor for a long time due to its rare occurrence. A detailed redescription of $S$. inermis, based on light microscopical study, was provided only by Moravec (1979). However, some taxonomically important features in cystidicolids, especially the structure of the mouth, can be properly studied only by using scanning electron microscopy (SEM). Of many Spinitectus species parasitizing fishes, this method has so far been used only in six species (Spinitectus gracilis Ward and Magath, 1917, Spinitectus carolini Holl, 1928, Spinitectus beaveri Overstreet, 1970, Spinitectus micracanthus Christian, 1972, Spinitectus jamundensis Thatcher and Padilha, 1977, Spinitectus minor De, 1988)

* Institute of Parasitology, Academy of Sciences of the Czech Republic, Branišovská 31, 37005 České Budějovice, Czech Republic. Tel. : (42-38) 41 158; Fax (42-38) 47 743; E-mail <moravec@paru.cas.cz>.
(Jilek and Crites, 1982; Petter and Morand, 1988; De, 1988). Nevertheless, these studies show that there may be, for example, distinct differences in the structure of the mouth among the Spinitectus species. S. inermis has not so far been studied by SEM. In this paper the results of a SEM study of $S$. inermis are presented.

\section{MATERIALS AND METHODS}

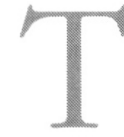
wo male specimens of $S$. inermis from the collection of the Institute of Parasitology, Academy of Sciences of the Czech Republic, were used for SEM study. They were from the material collected from Anguilla anguilla from the Břehyně Brook near Doksy, northern Bohemia, Czech Republic, on 9th September 1976 on which Moravec's (1979) redescription of $S$. inermis was based. Originally these nematodes were fixed in hot $4 \%$ formaldehyde and, after light microscopical examination, they were stored in $70 \%$ ethanol. For SEM examination, the nematodes were transferred to $4 \%$ formaldehyde, postfixed in $1 \%$ $\mathrm{OsO}_{4}$, dehydrated through graded ethanol and acetone and then subjected to critical point drying. The specimens were sputter-coated with gold and examined with a Tesla BS-300 scanning electron microscope at an accelerating voltage of $15 \mathrm{kV}$. 


\section{RESULTS}

he SEM examination of the cephalic end of the two male specimens of $S$. inermis shows that the oral opening is oval, dorsoventrally elongated, surrounded by four poorly developed, very low submedian labia, two subdorsal and two subventral, with broad base (Figs 1B, 2A), forming dorsolateral and dorsoventral margins of the oral opening. A simple, smooth, narrow, sclerotized structure ("sublabium" according to the terminology of Margolis, 1977), with a somewhat thickened free margin, is attached by its base to the inner surface of each labium (Figs 1B, 2A).
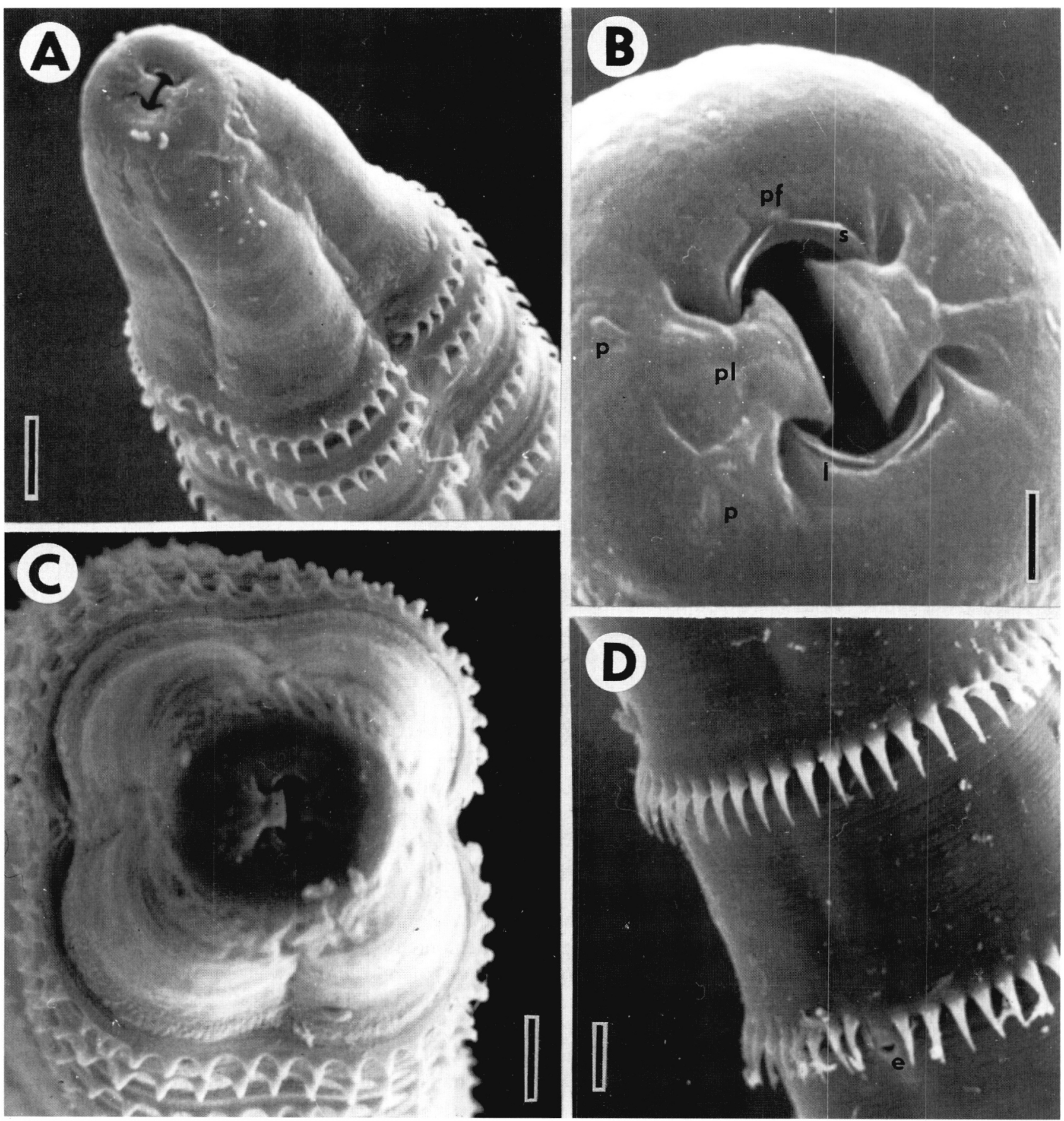

Fig. 1. - Spinitectus inermis (Zeder, 1800), male; SEM micrographs. A) Anterior end of body, sublateral view: B) subapical view of mouth; C) anterior end, apical view; D) third and fourth rings of cuticular spines, subventral views; e : excretory pore, 1: submedian labium, $\mathrm{p}$ : cephalic papilla, pf : papilla-like formation separating sublabia, pl : pseudolabium, $s$ : sublabium. Scale bars : A) $50 \mu \mathrm{m}$; B) $10 \mu \mathrm{m}$; C) $40 \mu \mathrm{m}$; D) $20 \mu \mathrm{m}$. 
In apical view, each labium gradually narrows towards both ends. The separation of both subdorsal and both subventral sublabia is very short, but distinct. The cuticle may form a small papilla-like structure (Fig. 1B) separating the right and the left sublabia. The width of the sublabia is much greater than their length.

The lateral pseudolabia (Figs 1B, 2A) are relatively large and project anteriorly beyond the labia. They do not touch each other by their inner margins and are continuous on their inner margin with the lateral anterior extensions of the buccal cavity wall. No distinct lateromedian plate, sepatated from the pseudolabium, is present. In apical view, the flat inner parts of the pseudolabia covering partly the oral opening are dorsoventrally expanded, forming two (one laterodorsal and one lateroventral) triangular extensions with sharp corners on each pseudolabium. Inner margins of both pseudolabia are dorsoventrally straight, parallel to each other (Figs 1B, 2A). The narrow, inner part of each pseudolabium continues posteriorly into a thickened pulp bearing two elongate submedian cephalic papillae (Figs 1B, 2A) and a small amphid.

Fig. $1 \mathrm{~A}, \mathrm{C}$ shows clearly that in properly extended specimens the body wall at the cervical region is somewhat depressed laterally and dorsoventrally, suggesting four longitudinal sectors, thus being responsible for the square appearance in apical view (Fig. 1C).

The SEM study has shown that the two anteriormost rings of cuticular spines are much closer to each other than the following rings, being interrupted on both sides of the body by lateral lines (Fig. 1A). Each of the two anterior rings consists of 48-50 spines in the two male specimens studied. The spines are simple, elongate, sharply pointed and no pore-like openings beneath them were observed (Fig. 2C).

The excretory pore is situated ventrally just below the fourth ring of spines (Figs 1D, 2C). A spine expected anterior to the excretory pore is absent (Fig. 2C). Deirids were not observed.

The present study confirms that there are ten pairs of caudal papillae in the male, four preanals, one adanals and five postanals. The papillae of the first and third pairs of preanals, as well as the adanals, are distinctly smaller than those of the second and the third pairs of preanals and, in contrast to the latter, they are located more laterally (Fig. 2B, E). The three hindmost postanal papillae are small and close together and the penultimate pair is situated ventrally. A pair of porelike outlets of phasmids is present just posterior to the last pair of caudal papillae (Fig. 2B). In addition to the paired papillae, a small unpaired median papilla is present on the anterior lip of the cloacal opening (Fig. 2B, E). The cloacal opening is a transverse slit, with the lips somewhat elevated. The tail is conical and ends in a shar point (Fig. 2D).
Ventral precloacal cuticular ridges (area rugosa) are well developed, and consist of several longitudinal rows composed of mostly numerous short, narrow, longitudinal cuticular elevations (Fig. 2D, E). At the region of the preanal papillae, the cuticular ridges are formed only by two distinct subventral longitudinal rows, which continue far anteriorly, and by a short median row (composed of only three cuticular elevations) situated in front of the unpaired preanal papilla. A small, transverse cuticular elevation is present immediately anterior to the unpaired papilla and posterior to the median row of cuticular elevations (Fig. 2B, E). Precloacal cuticular ridges extend anteriorly approximately to the level of the proximal end of the invaginated larger (left) spicule. In the region anterior to preanal papillae, longitudinal rows of cuticular ridges are more numerous (6).

\section{DISCUSSION}

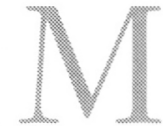

argolis (1977), De and Moravec (1979), Appy and Anderson (1982), Ko (1986), Fagerholm and Berland (1988) and others demonstrated that the characters in the structure of the mouth, which are not easily visible with the light microscope, are very important for the identification and systematics of cystidicolid nematodes. Jilek and Crites (1982) were the first to study the mouth structure in Spinitectus using SEM. They found the structure of the mouth of $S$. beaveri, a parasite of the marine fish Albula vulpes (L.) in Florida, to be considerably different from that of the three other North American species, S. gracilis, S. carolini and S. micracanthus parasitic in freshwater fishes. Petter (1984) compared the apical structures of all the then known apical structures of Spinitectus spp. (based on both light and scanning electron microscopy studies) and found that species parasitic in freshwater fishes of all continents had well developed pseudolabia bearing submedian papillae and amphids, whereas those from marine fishes had reduced pseudolabia, without supporting papillae and amphids. Two species, Spinitectus agonostomi Moravec and Baruš, 1971 and Spinitectus pachyuri Petter, 1984, from freshwater fishes belonging to essentially marine families (Mugilidae and Sciaenidae) had similar apical structures which were intermediate between the freshwater and marine forms.

The light microscopical appearance of apical structure of S. inermis was described by Rasheed (1965) and Moravec (1979). The latter author mentions that the mouth aperture is dorsoventrally elongated, with a sclerotized rim. The present study shows that "the sclerotized rim" of the mouth aperture is, in fact, composed of four submedian sclerotized plates attached by their bases to the inner surfaces of poorly developed 
TA
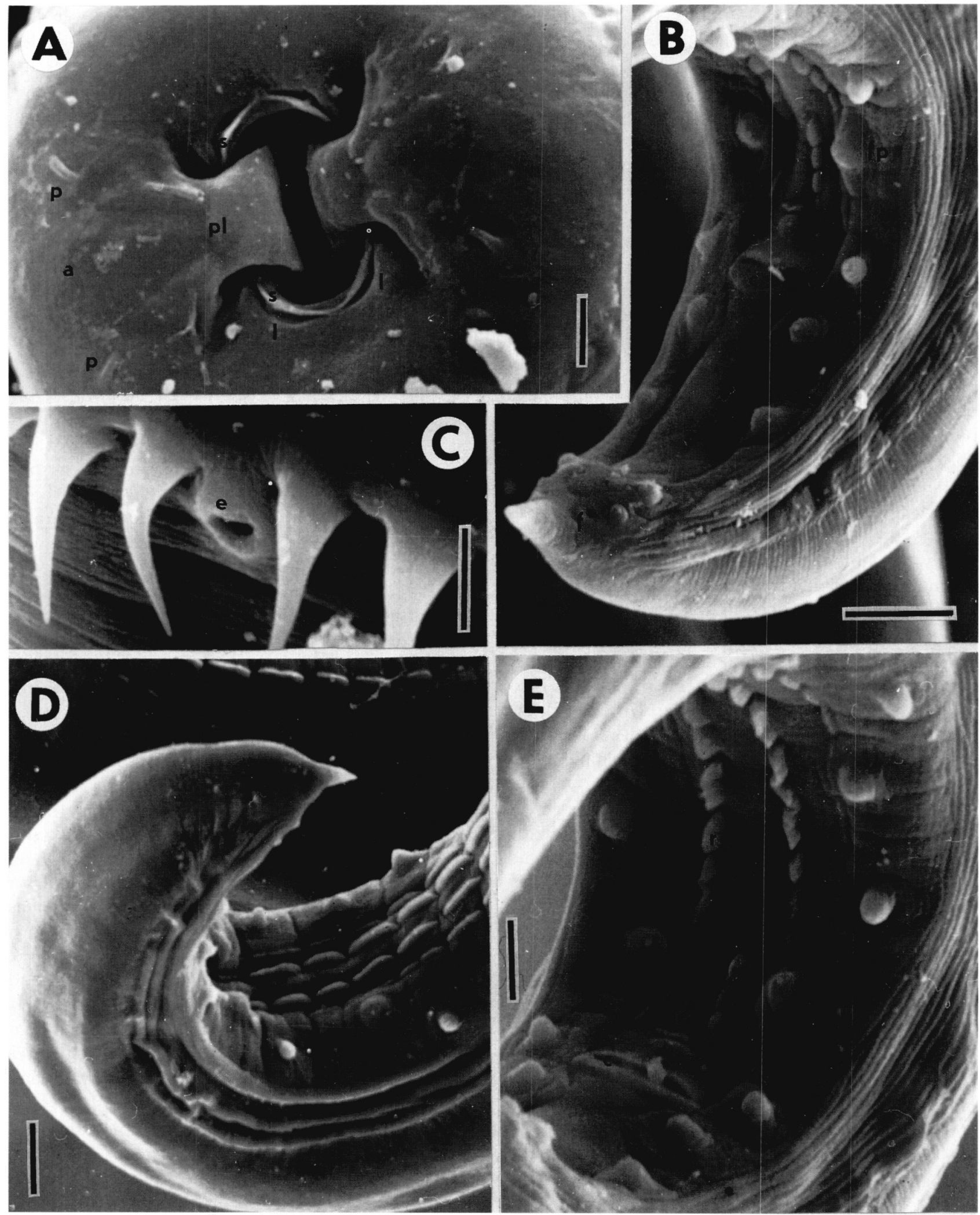

Fig. 2. - Spinitectus inermis (Zeder, 1800), male; SEM micrographs. A) Region of mouth, apical view; B) tail, ventrolateral view; C) region of excretory pore, ventral view; D) posterior end of body, ventrolateral view; E) precloacal region, ventral view; a : amphid, c : cloacal opening, $f$ : outlet of phasmid, fp : papilla of fourth preanal pair, $1:$ submedian labium, $\mathrm{p}:$ cephalic papilla, $\mathrm{pl}:$ pseudolabium, $\mathrm{r}:$ precloacal cuticular ridges, s : sublabium. Scale bars : A) $10 \mu \mathrm{m}$; B) $50 \mu \mathrm{m}$; C) $10 \mu \mathrm{m}$; D) $40 \mu \mathrm{m}$; E) $50 \mu \mathrm{m}$. 
submedian labia. Maggenti and Paxman (1971) and De and Moravec (1979) found similar structures in the mouth of the cystidicolid Cystidicoloides ephemeridarum (Linstow, 1872) which they had named as cheilorhabdion and sclerotized plates, respectively. Margolis (1977) named these structures as sublabia in Caballeronema Margolis, 1977 and the same terminology was used by Appy and Anderson (1982) in Capillospirura Skrjabin, 1924 and by Appy (1981), Ko (1985) and Fagerholm and Berland (1988) in Ascarophis (van Beneden, 1871).

The only species of Spinitectus in which sublabia have been described is $S$. jamundensis Thatcher et Padilha, 1977 from South American freshwater fishes, but their size and form are very different from those reported in other cysticicolids (Petter and Morand, 1988) or from those found in $S$. inermis. The presence of sublabia in $S$. inermis indicates affinities of this species to some cystidicolids of marine origin (e. g., Ascarophis, Cystidicoloides, Capillospirura, Caballeronema) which may be associated with its host type, the eel, belonging to the essentially marine order Anguilliformes. Also $S$. jamundensis shows some affinities to marine forms, this being reflected in the size and structure of pseudolabia and the presence of a well separated median plate in the mouth (the latter is absent in S. inermis). However, the character of pseudolabia in $S$. inermis is typical of freshwater species of Spinitectus (Petter, 1984). Therefore, in addition to $S$. agonostomi, $S$. pachyuri and S. jamundensis, S. inermis also has apical structures intermediate between those of freshwater and marine congeneric forms.

Moravec (1979) has reported that there are apparently considerable differences in the numbers of cuticular spines in $S$. inermis specimens. He found 70 spines in the first ring of a medium sized female, whereas Schneider (1866) and Chubb (1961) reported 56 and 56-60 spines per ring, respectively. The drawing by Rasheed (1965) indicates the presence of 83 spines per ring. The present study has shown $48-50$ spines to be present per ring in the two $S$. inermis males. Jilek and Crites (1982) found a distinct pore-like opening beneath each cuticular spine in $S$. beaveri, but the present study shows that these openings are absent from $S$. inermis. It has also confirmed the position of the excretory pore, which is an important taxonomic feature of the Spinitectus spp. (Moravec, 1979; Petter and Morand, 1988; Boomker and Puylaert, 1994)

The present study shows, for the first time in $S$. inermis, the presence of a median unpaired papilla in front of the cloacal opening. Such papilla has so far been described only rarely in Spinitectus species (e. g., in S. minusculus Boomker and Puylaert, 1994).

\section{ACKNOWLEDGEMENTS}

T he author's thanks are due to the staff of the Laboratory of Electron Microscopy, Institute of Parasitology, AS CR, in České Buď̌jovice for their technical assistance. This study was supported by the grant no. 508/94/0284 from the Grant Agency of the Czech Republic.

\section{REFERENCES}

Appy R.G. Species of Ascarophis van Beneden, 1870 (Nematoda: Cystidicolidae) in North Atlantic fishes. Canadian Journal of Zoology, 1981, 59, 2193-2205.

Appy R.G. \& ANDERson R.C. The genus Capillospirura Skrjabin, 1924 (Nematoda: Cystidicolidae) of sturgeons. Canadian Journal of Zoology, 1982, 60, 194-202.

BOOMKER J. \& PUYlaERT F.A. Eight new Afrotropical Spinitectus spp. (Nematoda: Cystidicolidae) from freshwater fishes with a key to the members of the genus in the Region. Onderstepoort Journal of Veterinary Research, 1994, 61, 127-142.

ChubB J.C. A preliminary investigation of the parasite fauna of the fish of Llyn Tegid (Bala Lake), Merionthshire. Unpublished Ph. D. thesis, University of Liverpool, 1961 (ex Cordero del Campillo and Alvarez-Pellitero, 1976).

Cordero del Campillo M. \& Alvarez-Pellitero M.P. Spinitectus gordoni n. sp. (Nematoda: Spiruroidea) from brown and raibow trouts in NW Spain. Revista Iberica de Parasitologia, 1976, 36, 35-66.

DE N.C. Data on the morphology of the nematode Spinitectus minor (Stewart, 1914) (Nematoda: Cystidicolidae). Folia Parasitologica, 1985, 35, 41-45.

De N.C. \& Moravec F. Some new data on the morphology and development of the nematode Cystidicoloides tenuissima (Zeder, 1800). Folia Parasitologica, 1979, 26, 231$237+$ Plts. I, II.

Fagerholm H.P. \& Berland B. Description of Ascarophis arctica Poljansky, 1952 (Nematoda: Cystidicolidae) in Baltic Sea fishes. Systematic Parasitology, 1988, 11, 151-158.

Jilek R. \& Crites J.L. Comparative morphology of the North American species of Spinitectus (Nematoda: Spirurida) analyzed by scanning electron microscopy. Transactions of the American Microscopical Society, 1982, 101, 126-134.

Ko R.C. Ascarophis minuta n. sp. (Nematoda: Cystidicolidae) from a scorpaenid fish, Sebasticus marmoratus, in Hong Kong, southern China. Tropical Biomedicine, 1985, 2, 99105.

Ko R.C. A preliminary review of the genus Ascarophis van Beneden, 1871 (Nematoda: Cystidicolidae) of the gastrointestinal tract of fishes. Department of Zoology, University of Hong Kong, Occasional Publications, 1986, 54 p.

Maggenti A.R. \& Paxman G.A. Sterliadochona pedispicula sp. n. (Nematoda: Spirurinae) from Salmo gairdnerii (Richardson), and a discussion of the genera Sterliadochona Skrjabin, 1946 and Cystidicolides Skinker, 1931. Pro- 
ceedings of the Helminthological Society of Washington, $1971,38,210-214$.

MARGOLIS L. Caballeronema gen. nov. for Metabronema wardlei Smedley, 1934 (Nematoda, Spiruroidea) from the marine fish Scorpaenichthys marmoratus from the Pacific coast of Canada. Excerta Parasitológica en memoria del doctor Eduardo Caballero y Caballero, Instituto de Biología, Universidad Nacional Autónoma de México, Publicaciones especiales 4, 1977, pp. 447-454.

Moravec F. Redescription of the nematode Spinitectus inermis parasitic in eels, Anguilla anguilla, of Europe. Acta Societatis Zoologicae Bohemoslovacae, 1979, 43, 35-42.

Moravec F. Parasitic nematodes of freshwater fishes of Europe. Academia and Kluwer Acad. Publishers, Prague and Dordrecht, Boston, London, 1994, 473 p.

Petter A.J. Nématodes de poissons du Paraguay II. Habronematoidea (Spirurida). Description de 4 espèces nouvelles de la famille des Cystidicolidae. Revue suisse de Zoologie, 1984, 91, 935-952.

Petter A.J. \& Morand S. Nématodes de poissons du Paraguay. IV. Redescription de Spinitectus jamundensis Thatcher et Padilha, 1977 (Cystidicolidae, Nematoda). Revue suisse de Zoologie, 1988, 95, 377-384.

RASHEED S. Observations on the spiruroid nematodes of fish with a revision of the genus Metabronema Yorke and Maplestone, 1926. Zeitschrift für zoologische Systematic und Evolutionsforschung, 1965, 3, 359-387.

SCHNEIDER A. Monographie der Nematoden. Berlin, 1866, 357 p. +28 Plts.

Reçu le 15 novembre 1995 Accepté le 25 janvier 1996 